\title{
Usability Attributes for Mobile Applications: A Systematic Review
}

\author{
Ryan Alturki and Valerie Gay \\ Faculty of Engineering and Information Technology, University of Technology Sydney, \\ 15 Broadway, Ultimo NSW 2007, Australia \\ Ryan.M.Alturki@student.uts.edu.au, Valerie.Gay@uts.edu.au
}

\begin{abstract}
The usability of mobile applications (apps) is an emerging area of research because of the increasing use of mobile devices around the world. App development is challenging because each application has its own purpose and each individual user has different needs and expectations from the apps. There are various apps available for each purpose and the success of the application depends on its usefulness. This paper presents a systematic review of some of the most contemporary apps and highlights their usability attributes. It discusses usability models, frameworks and guidelines outlined in previous research for designing apps with enhanced usability characteristics. Based on this research, comprehensive guidelines for mobile apps' usability can then be provided.
\end{abstract}

Keywords: Usability, Mobile Application, Usability Attributes

\section{Introduction}

The traditional usability guidelines used in desktop applications are not very much applicable to the apps [1]. Apps usability attributes are different; therefore, we need to specify usability attributes that are essential and important for apps [2]. The important usability attributes expected in any app is: Effectiveness, Satisfaction, Efficiency, Learnability, Errors and Memorability as well as the quality characteristics outlined in ISO 9126 [3], [4], [5], [6]. Some of the usability attributes may overlap in meaning but have been used with different names by different researchers.

Most of the guidelines are for usability testing but most of them are not applicable to apps because mobile apps have unique features and changing context [1]. Furthermore, the work available does not have any consensus on the factors of usability. A recent study identified user, task and context as the main factors of usability [3]. However, the study was lacking due to certain limitations. The researchers found it hard to find the relevant papers and it affected the results. The papers included were from 2008 to 2010 because smartphone apps had become popular during this period and there had not been much research done on mobile apps usability till that time. A review was conducted on usability characteristics of apps but the work also lacked some of the recent developments in apps' usability [7]. 
This article seeks to contribute to important research concerning the usability attributes of apps. The purpose of this research is to conduct a systematic review that reveals the most prominent and recent usability attributes that have been discussed and have emerged in the research. This study will be useful in building future guidelines for developing apps that have all the essential usability attributes. This work stands out because it discusses some of the most contemporary research.

\section{The Systematic Review}

We undertook a systematic review to search for published, peer-reviewed articles that investigated usability attributes in mobile apps. We utilised the terminology outlined in the table below (Table 1) to look for research papers covering usability attributes in mobile devices and applications. We sought to incorporate all the related terms that could provide us with articles relevant to this topic.

We referred to ACM Digital Library, EBSCO, IEEE Xplore, PsycINFO, Communication and Mass Media Complete, Computers and Applied Sciences Complete, ProQuest Computer Science Collection, Computer Source and Web of Science

We tried to include the most recent articles starting from 2010, which were based on app usability. We have followed the methodology from [8] and the flow chart below shows how the systematic review was undertaken.

Table 1. Keywords used in the systematic review relating to usability attributes of mobile applications

\begin{tabular}{|c|c|c|}
\hline Search Lines & Search terms & Filtered by \\
\hline Line 1 & $\begin{array}{l}\text { Mobile Device OR Mobile Phone OR Smart } \\
\text { Phone }\end{array}$ & Title/Abstract \\
\hline 2. AND & Applications OR Apps & Title/Abstract \\
\hline 3. AND & Usability & Title/Abstract \\
\hline 4. AND & $\begin{array}{l}\text { Mobile Application Usability OR Mobile } \\
\text { App Usability }\end{array}$ & Title/Abstract \\
\hline 5. AND & $\begin{array}{c}\text { Application Usability Attributes OR Apps } \\
\text { Usability Attributes }\end{array}$ & Title/Abstract \\
\hline 6. AND & $\begin{array}{c}\text { Mobile Application Usability Attributes OR } \\
\text { Mobile Apps Usability Attributes }\end{array}$ & Title/Abstract \\
\hline
\end{tabular}




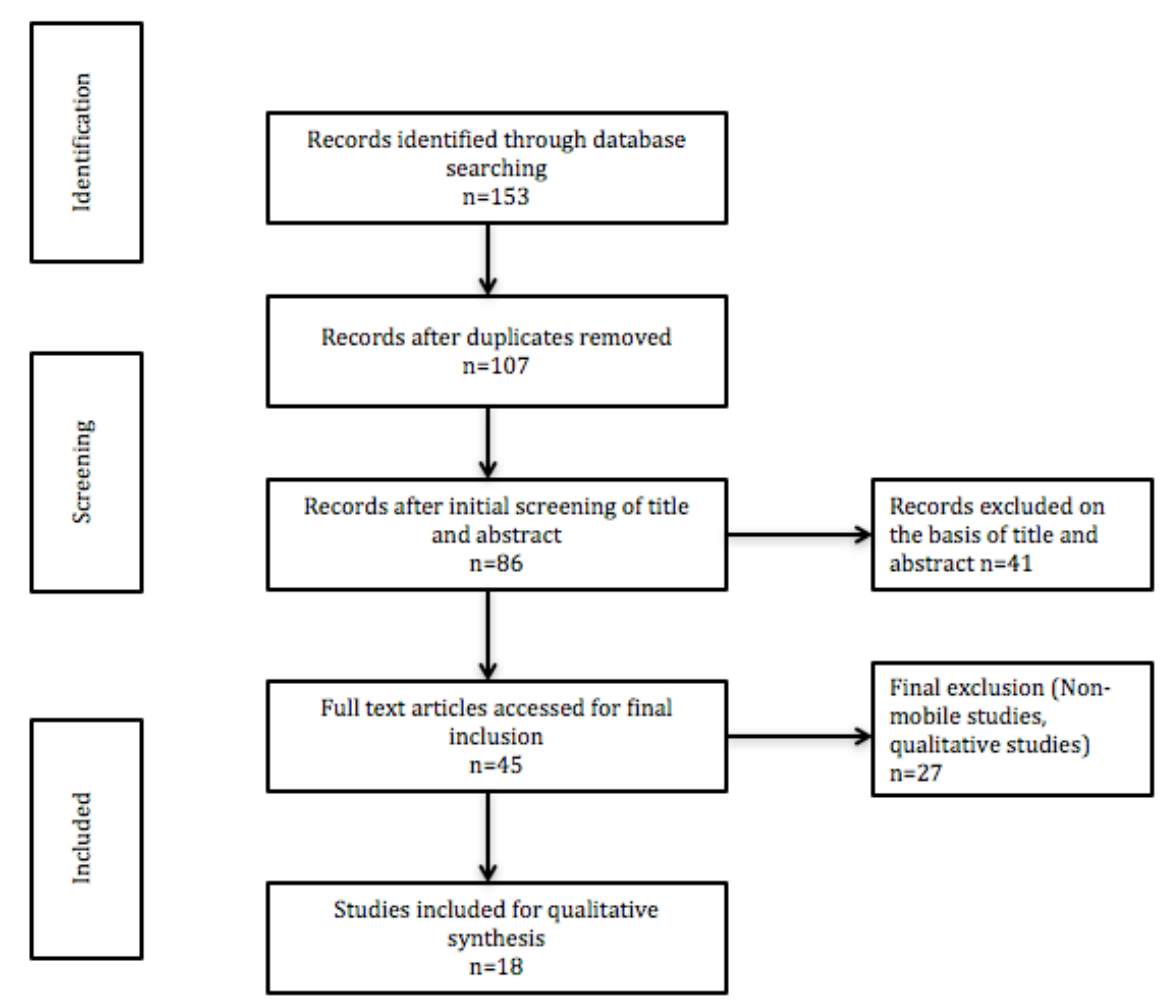

Fig. 1. Methodology for the systematic review

\section{Results}

We conducted a systematic review of usability attributes in mobile apps. We looked for articles that discussed usability attributes in mobile devices and applications. We also conducted a comprehensive survey on usability of apps and tried to figure out the important attributes discussed in these papers. Eighteen relevant articles were included which have been published and peer reviewed. 
Table 2. Usability attributes in apps

\begin{tabular}{|c|c|c|}
\hline $\begin{array}{l}\text { Study's } \\
\text { Date }\end{array}$ & $\begin{array}{l}\text { Usability } \\
\text { Attributes }\end{array}$ & Research \\
\hline 2010 & $\begin{array}{l}\text { Enjoyment, } \\
\text { usefulness and } \\
\text { ease of use. }\end{array}$ & $\begin{array}{l}\text { A new User Interface (UI) for mobile phones is } \\
\text { presented in this article, which makes the use of } \\
\text { UGC services both more efficient and easier. UI } \\
\text { has two main mobile Web } 2.0 \text { technologies: multi- } \\
\text { display buttons, tag and tag cloud, which increase } \\
\text { the flexibility of individual users' buttons and } \\
\text { display size. The article not only describes the new } \\
\text { UI interface but also investigates whether it aids in } \\
\text { enhancing exploratory browsing within mobile } \\
\text { User-Generated Content (UGC) services [9]. }\end{array}$ \\
\hline 2010 & $\begin{array}{l}\text { Network } \\
\text { connection } \\
\text { quality, user } \\
\text { distraction and } \\
\text { user mobility. }\end{array}$ & $\begin{array}{l}\text { The article aims to fill a gap in the field of } \\
\text { Mobile Information Technology by coming up with } \\
\text { clear guidelines for designing mobile information } \\
\text { systems. Building on prior studies this research } \\
\text { introduces a three-step conceptual model that can } \\
\text { be used by managers to design effective } \\
\text { information systems. The research found that a } \\
\text { network connection's poor quality and high user } \\
\text { distraction are very challenging features for mobile } \\
\text { Information System (IS) design; user interface } \\
\text { should be given particular attention [10]. }\end{array}$ \\
\hline 2010 & $\begin{array}{l}\text { Menu icons, } \\
\text { text and colour. }\end{array}$ & $\begin{array}{l}\text { This article studied the effects of product } \\
\text { aesthetics in usability testing on various outcome } \\
\text { variables. The research asked whether changing the } \\
\text { appearance of mobile phones has an impact upon } \\
\text { usability. } 60 \text { adolescents were asked to use two } \\
\text { functionally identical mobile devices but with } \\
\text { different visual appearances (highly appealing or } \\
\text { not appealing) to find out if there is any relation } \\
\text { between usability, perceived attractiveness and } \\
\text { performance measures of the product. The findings } \\
\text { were that the appealing appearance has a more } \\
\text { highly perceived usability, perceived product } \\
\text { attractiveness and user performance due to lower } \\
\text { task completion time, less errors and higher } \\
\text { interaction efficiency [11]. }\end{array}$ \\
\hline 2011 & $\begin{array}{l}\text { Presentation } \\
\text {, adaptation of } \\
\text { web pages, } \\
\text { accuracy and } \\
\text { search time. }\end{array}$ & $\begin{array}{l}\text { The researchers developed and tested specific } \\
\text { mobile apps in lab research settings. Testers' } \\
\text { performances were used to evaluate usability } \\
\text { attributes. The results of the research showed that } \\
\text { presentation adaptation greatly enhanced user } \\
\text { perception and performance of mobile Web }\end{array}$ \\
\hline
\end{tabular}




\begin{tabular}{|c|c|c|}
\hline & & $\begin{array}{l}\text { browsing. They discovered that less complexity in } \\
\text { information search tasks improves accuracy and } \\
\text { reduces search time [12]. }\end{array}$ \\
\hline 2011 & $\begin{array}{c}\text { Icon } \\
\text { characteristics }\end{array}$ & $\begin{array}{l}\text { The study aimed to find out how mobile devices } \\
\text { could be made easier to use for adults over } 65 \text { years } \\
\text { of age. Specifically, alternative mobile apps were } \\
\text { benchmarked by manipulating icon characteristics. } \\
\text { It was found that the elderly face more problems } \\
\text { using icons on existing mobile devices. However, } \\
\text { icon characteristics, which have a close semantic } \\
\text { meaning (i.e. a close relationship between the } \\
\text { portrayed object and its connected function) and are } \\
\text { well-known and specific were found to enhance and } \\
\text { improve icon usability for elderly people [13]. }\end{array}$ \\
\hline 2012 & $\begin{array}{l}\text { Customer } \\
\text { needs, design, } \\
\text { feedback, } \\
\text { innovativeness, } \\
\text { satisfaction and } \\
\text { efficiency. }\end{array}$ & $\begin{array}{l}\text { This research developed and used a } \\
\text { questionnaire on mobile phones to find out if there } \\
\text { was any relationship between usability and the } \\
\text { success of the product. The researchers reviewed } \\
\text { the factors of product success and existing usability } \\
\text { studies to develop a questionnaire. The usability } \\
\text { and success factors of mobile phones were } \\
\text { evaluated by the participants. The results showed } \\
\text { that customer needs, design and innovativeness } \\
\text { were not only important success factors but also } \\
\text { increased attention ought to be given to feedback, } \\
\text { efficiency and satisfaction to improve the usability } \\
\text { of mobile phones [14]. }\end{array}$ \\
\hline 2012 & $\begin{array}{l}\text { Screen size, } \\
\text { colour, weight } \\
\text { of device, text } \\
\text { source, extra } \\
\text { batteries etc. }\end{array}$ & $\begin{array}{l}\text { This paper aims to highlight the expected quality } \\
\text { characteristics of apps with a detailed and reviewed } \\
\text { discussion mostly about usability characteristics, } \\
\text { being external characteristics of apps as according } \\
\text { to ISO } 9126 \text { [7]. }\end{array}$ \\
\hline 2013 & $\begin{array}{l}\text { Errors, task } \\
\text { completion } \\
\text { time, and } \\
\text { effectiveness. }\end{array}$ & $\begin{array}{l}\text { The article compares mobile usability in Iran and } \\
\text { Turkey. The research concludes that usability is } \\
\text { impacted by not only religious, ethnic, or cultural } \\
\text { issues but also contextual features which are } \\
\text { endemic to both Turkey and Iran [15]. }\end{array}$ \\
\hline 2013 & $\begin{array}{l}\quad \text { Efficiency, } \\
\text { satisfaction, } \\
\text { effectiveness, } \\
\text { aesthetic, } \\
\text { usefulness, } \\
\text { simplicity, } \\
\text { learnability, } \\
\text { understandable, } \\
\text { intuitiveness } \\
\text { and }\end{array}$ & $\begin{array}{l}\text { The main objective of the study is to propose a } \\
\text { set of usability dimensions that should be } \\
\text { considered when evaluating and designing mobile } \\
\text { apps. The model introduced is based on the reviews } \\
\text { of previously related studies, which were analysed } \\
\text { by using a content analysis approach. Ten usability } \\
\text { attributes were outlined in the model. The model } \\
\text { introduced could be of assistance to practitioners } \\
\text { and researchers as a guideline to design usable } \\
\text { mobile apps [16]. }\end{array}$ \\
\hline
\end{tabular}




\begin{tabular}{|c|c|c|}
\hline & attractiveness. & \\
\hline 2013 & Security & $\begin{array}{l}\text { The paper discusses the relationship between } \\
\text { security and usability in mobile platforms; and how } \\
\text { reducing various security threats can improve the } \\
\text { usability of mobile apps [17]. }\end{array}$ \\
\hline 2013 & $\begin{array}{l}\text { How the } \\
\text { satisfaction } \\
\text { attribute of } \\
\text { apps can be } \\
\text { improved by } \\
\text { making them } \\
\text { more energy } \\
\text { efficient. }\end{array}$ & $\begin{array}{l}\text { The approach proposed in the paper is } \\
\text { convenient for developers and provides a better } \\
\text { estimate of energy consumption at code level. Pre- } \\
\text { instruction energy modelling and program analysis } \\
\text { is used to achieve these results. The new approach } \\
\text { can estimate energy consumption for mobile apps } \\
\text { to ten per cent of the ground truth [18]. }\end{array}$ \\
\hline 2013 & $\begin{array}{l}\quad \text { Efficiency, } \\
\text { satisfaction, } \\
\text { effectiveness, } \\
\text { learnability, } \\
\text { errors, } \\
\text { memorability } \\
\text { and cognitive } \\
\text { load. }\end{array}$ & $\begin{array}{l}\text { Review of usability models was conducted and } \\
\text { outlined seven usability attributes. The researchers } \\
\text { believed cognitive load has been overlooked in } \\
\text { previous usability models [3]. }\end{array}$ \\
\hline 2014 & $\begin{array}{l}\quad \text { Efficiency, } \\
\text { user } \\
\text { satisfaction, } \\
\text { and technical } \\
\text { effectiveness. }\end{array}$ & $\begin{array}{l}\text { The research objective was to test the usability } \\
\text { (efficiency, user effectiveness, and technical } \\
\text { effectiveness) of a developed mobile app } \\
\text { (Reactivate) in obese adolescents. A field study was } \\
\text { conducted on obese children who were asked to use } \\
\text { the app to perform tasks to test its usability. The } \\
\text { tasks had } 5 \text { categories: to create a message; to enter } \\
\text { personal settings; to use the goal-setting feature; to } \\
\text { find and to answer surveys; and to enter } \\
\text { descriptions or details of weight and height. } \\
\text { Standardized (SUMI) was completed by each } \\
\text { participant to determine the satisfaction of the user. } \\
\text { SUMI measures five aspects of user satisfaction: } \\
\text { effect, controllability, helpfulness, efficiency and } \\
\text { learnability. SUMI scores and the mean relative } \\
\text { user efficiency were explored using descriptive } \\
\text { statistics. The mean scores confirmed that } \\
\text { Reactivate was a useful app and users responded } \\
\text { with great interest [19]. }\end{array}$ \\
\hline 2015 & Satisfaction & $\begin{array}{l}\text { People with ASD (Autism Spectrum Disorder) } \\
\text { usually lack familiarity and experience with new } \\
\text { technologies; therefore, usability of apps developed } \\
\text { specifically for children with autism is very } \\
\text { important. The paper compares the usability of two } \\
\text { Arabic apps available on the Apple Store. Various } \\
\text { measurement tools were used to collect quantitative }\end{array}$ \\
\hline
\end{tabular}




\begin{tabular}{|c|c|c|}
\hline & & $\begin{array}{l}\text { and qualitative data to determine the level of user } \\
\text { satisfaction with the apps. Recommendations were } \\
\text { then made on how further the usability of these } \\
\text { apps can be improved [20]. }\end{array}$ \\
\hline 2015 & \begin{tabular}{l}
\multicolumn{1}{c}{ Efficiency } \\
effectiveness, \\
satisfaction, \\
attractiveness, \\
learnability, \\
operability and \\
understanding.
\end{tabular} & $\begin{array}{l}\text { This paper conducted a systematic literature } \\
\text { review to investigate empirical usability evaluation } \\
\text { processes described in different m-health apps } \\
\text { studies. The research showed that the usability } \\
\text { attributes evaluated mostly in m-health apps were } \\
\text { operability and effectiveness. The results showed } \\
\text { that using automated mechanisms can improve the } \\
\text { methods of empirical evaluation employed in } \\
\text { usability. The paper could be useful for developers } \\
\text { and researchers who are looking to create apps with } \\
\text { better usability. The study also demonstrates the } \\
\text { benefits of adapting health apps to the needs of } \\
\text { users [21]. }\end{array}$ \\
\hline 2015 & $\begin{array}{l}\quad \text { Efficiency, } \\
\text { effectiveness } \\
\text { and } \\
\text { satisfaction. }\end{array}$ & $\begin{array}{l}\text { This paper aimed to assess the usability of } \\
\text { Chongqing University Library App and give } \\
\text { recommendations for improving the usability of } \\
\text { apps. Usability testing involved pre-test } \\
\text { questionnaires, achieving tasks, and post-test } \\
\text { surveys. Three attributes were measured: } \\
\text { effectiveness, efficiency and user satisfaction. The } \\
\text { results showed that app was effective but } \\
\text { improvement was needed for efficiency. For the } \\
\text { user satisfaction, 'usefulness' had the highest score } \\
\text { and 'clarity' the lowest. The descriptions were not } \\
\text { clear and sometimes confused users. However, the } \\
\text { services the app provided were appealing and } \\
\text { appreciated by most users. After measuring UX, the } \\
\text { paper recommends ways to enhance the usability of } \\
\text { the App [22]. }\end{array}$ \\
\hline 2016 & \begin{tabular}{l}
\multicolumn{1}{c}{ Visibility, } \\
scrolling, \\
navigation, \\
interaction, \\
satisfaction, \\
convenience, \\
and simplicity.
\end{tabular} & $\begin{array}{l}\text { The paper compared four widely used mobile } \\
\text { spreadsheet apps: Google Drive, Documents to Go, } \\
\text { OfficeSuite Viewer } 6 \text { and ThinkFree Online. } \\
\text { Measures for each usability attribute were gleaned } \\
\text { from a survey. These surveys were created to } \\
\text { address the measures based on comparative criteria } \\
\text { supplied in the analysis. The results also indicate } \\
\text { that there is little difference between the apps in } \\
\text { their end results and the aspects conducted in this } \\
\text { survey [23]. }\end{array}$ \\
\hline 2016 & $\begin{array}{l}\text { Satisfaction } \\
\text { and user } \\
\text { feeling. }\end{array}$ & $\begin{array}{l}\text { The article selects all touchscreen mobile } \\
\text { devices and various components that affect their } \\
\text { usability. Analytic Network Process (ANP) and } \\
\text { Technique for Order of Preference by Similarity to }\end{array}$ \\
\hline
\end{tabular}




\begin{tabular}{|l|l|}
\hline & $\begin{array}{l}\text { Ideal Solution (TOPSIS) were used to find which } \\
\text { mobile devices were superior and which usability } \\
\text { features were most important [24]. }\end{array}$ \\
\hline
\end{tabular}

\section{Results Evaluation}

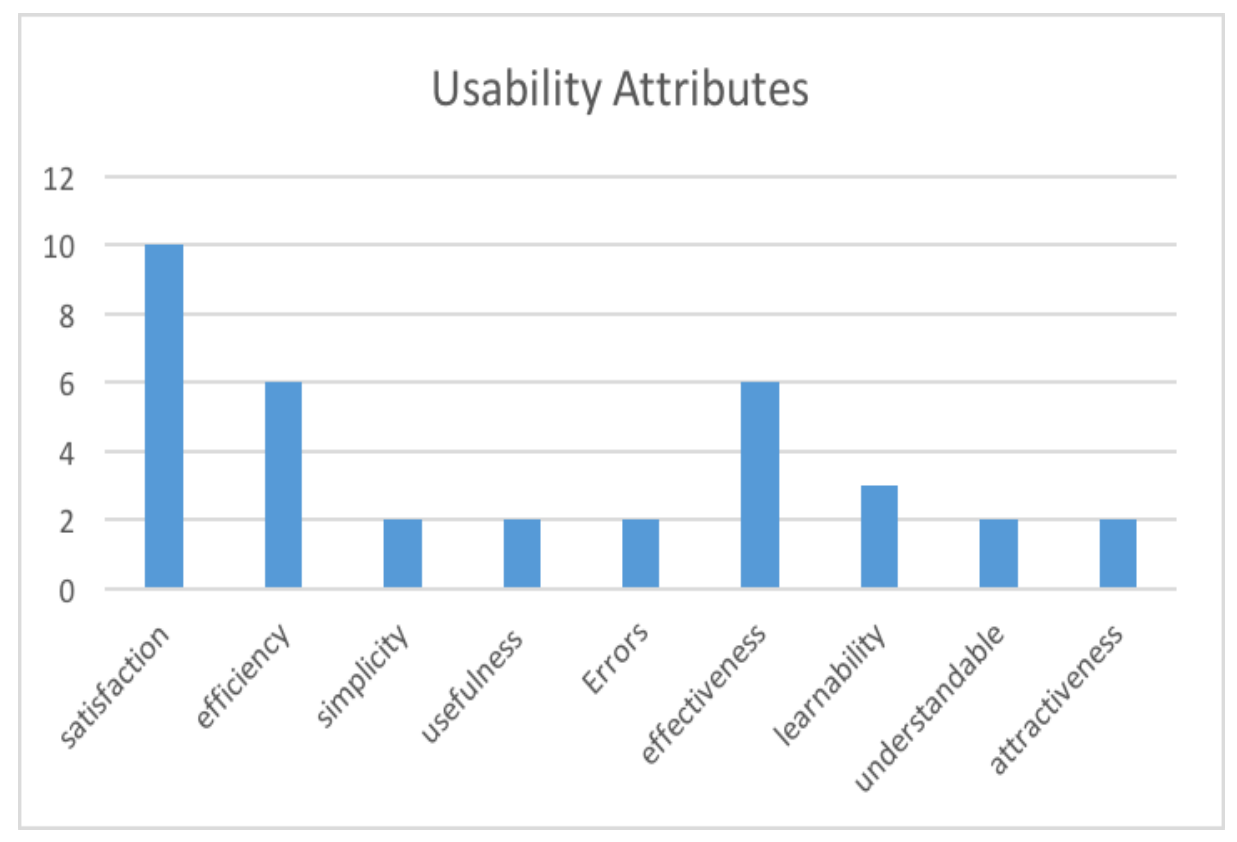

Fig. 2. Usability attributes in mobile apps

Figure 2 shows the mobile apps' usability attributes. Satisfaction is the most highly mentioned amongst studies at 10 times. Then, both effectiveness and efficiency at 6 times. Next, learnability was cited 3 times. Afterward, simplicity, usefulness, errors, understandable and attractiveness named 2 times. All the other attributes, such as memorability and cognitive load were only cited once.

\section{Conclusion}

This review shows that usability in apps has been discussed from various points of view by many authors. Some studies provide guidelines for improving usability whilst others compare usability attributes amongst different apps. Usability has been 
discussed from numerous angles between 2010 and 2016. Most of the work discussed in the beginning of the study involved research in lab settings; however more recent research usually took place in field settings. Earlier research was aimed at testing usability attributes in apps or emphasising the importance of certain attributes. Next, most researchers were interested in comparing different applications to test usability. Then, usability attributes have been evaluated for some practical apps and there has been a focus on adding something new to these. Recent work has also included users' acceptance and expert reviews as evaluating procedures for determining the usability of applications. Some of the recent work focuses specifically on improving usability in apps related to various fields ranging from health to social networking. Usability criteria are always evolving and the needs of people are changing rapidly so new dimensions of usability have been discussed in some of the recent research. The attributes that are emerging in the new research are related to the ease of use of the application when performing multiple tasks, intuitiveness, security and power consumption. These attributes can be debated as being part of those defined in the traditional literature, but in apps, there is a need to mention them separately to emphasise their importance.

The evaluation of the results shows that satisfaction is the most highly mentioned amongst studies at 10 times followed by both effectiveness and efficiency at 6 times.

This research shows that there are numerous usability attributes and it is difficult for designers to include them all into one app. The best they can do is improve the usability of the app by keeping its nature in mind. This research will be used to outline usability guidelines for developing applications with enhanced usability. This is only possible when the developer is aware of the attributes that enhance usability.

\section{References}

1. Zhang, D., and Adipat, B. 2005. "Challenges, Methodologies, and Issues in the Usability Testing of Mobile Applications," International Journal of Human-Computer Interaction (18:3), pp. 293-308.

2. Gafni, R. 2009. "Usability Issues in Mobile-Wireless Information Systems," Issues in Informing Science and Information Technology (6), pp. 755-769.

3. Harrison, R., Flood, D., and Duce, D. 2013. "Usability of Mobile Applications: Literature Review and Rationale for a New Usability Model," Journal of Interaction Science (1:1), pp. 1-16.

4. Popa, M. 2010. "Audit Process During Projects for Development of New Mobile It Applications," Informatica Economica (14:3), p. 34.

5. Pocatilu, P., and Boja, C. 2009. "Quality Characteristics and Metrics Related to MLearning Process," Amfiteatru Economic (11:26), pp. 346-354.

6. Fleming, I. 2016. "An Overview of the Iso 9126-1 Software Quality Model Definition, with an Explanation of the Major Characteristics.", from http://www.sqa.net/iso9126.html

7. Rabi'u, S., Ayobami, A. S., and Hector, O. P. 2012. "Usability Characteristics of Mobile Applications," Proceedings of International Conference on Behavioural \& Social Science Research (ICBSSR), Kampar, Malaysia.(Indexed by Thomson Reuters). 
8. Alturki, R. M., and Gay, V. 2016. "A Systematic Review on What Features Should Be Supported by Fitness Apps and Wearables to Help Users Overcome Obesity," International Journal of Research in Engineering and Technology (05: 09).

9. Functionality of Mobile Apps in Health Interventions: A Systematic Review of the Literature," JMIR mHealth and uHealth (3:1), p. e20.

10. Kim, S., Lee, I., Lee, K., Jung, S., Park, J., Kim, Y. B., Kim, S. R., and Kim, J. 2010. "Mobile Web 2.0 with Multi-Display Buttons," Communications of the ACM (53:1), pp. 136-141.

11. Gebauer, J., Shaw, M. J., and Gribbins, M. L. 2010. "Task-Technology Fit for Mobile Information Systems," Journal of Information Technology (25:3), pp. 259-272.

12. Sonderegger, A., and Sauer, J. 2010. "The Influence of Design Aesthetics in Usability Testing: Effects on User Performance and Perceived Usability," Applied ergonomics (41:3), pp. 403-410.

13. Adipat, B., Zhang, D., and Zhou, L. 2011. "The Effects of Tree-View Based Presentation Adaptation on Mobile Web Browsing," Mis Quarterly (35:1), pp. 99122.

14. Leung, R., McGrenere, J., and Graf, P. 2011. "Age-Related Differences in the Initial Usability of Mobile Device Icons," Behaviour \& Information Technology (30:5), pp. 629-642.

15. Kim, K., Proctor, R. W., and Salvendy, G. 2012. "The Relation between Usability and Product Success in Cell Phones," Behaviour \& Information Technology (31:10), pp. 969-982.

16. Aryana, B., and Clemmensen, T. 2013. "Mobile Usability: Experiences from Iran and Turkey," International Journal of Human-Computer Interaction (29:4), pp. 220-242.

17. Baharuddin, R., Singh, D., and Razali, R. 2013. "Usability Dimensions for Mobile Applications-a Review," Res. J. Appl. Sci. Eng. Technol (5), pp. 2225-2231.

18. Boja, C., Doinea, M., and Pocatilu, P. 2013. "Impact of the Security Requirements on Mobile Applications Usability," Academy of Economic Studies. Economy Informatics (13:1), p. 64

19. Hao, S., Li, D., Halfond, W. G., and Govindan, R. 2013. "Estimating Mobile Application Energy Consumption Using Program Analysis," Software Engineering (ICSE), 2013 35th International Conference on: IEEE, pp. 92-101.

20. O'Malley, G., Dowdall, G., Burls, A., Perry, I. J., and Curran, N. 2014. "Exploring the Usability of a Mobile App for Adolescent Obesity Management," JMIR mHealth and uHealth (2:2), p. e29.

21. Al-Wakeel, L., Al-Ghanim, A., Al-Zeer, S., and Al-Nafjan, K. 2015. "A Usability Evaluation of Arabic Mobile Applications Designed for Children with Special Needs-Autism," Lecture Notes on Software Engineering (3:3), p. 203.

22. Zapata, B. C., Fernández-Alemán, J. L., Idri, A., and Toval, A. 2015. "Empirical Studies on Usability of Mhealth Apps: A Systematic Literature Review," Journal of medical systems (39:2), pp. 1-19.

23. Wei, Q., Chang, Z., and Cheng, Q. 2015. "Usability Study of the Mobile Library App: An Example from Chongqing University," Library Hi Tech (33:3), pp. 340-355.

24. Chintapalli, V. V., Tao, W., Meng, Z., Zhang, K., Kong, J., and Ge, Y. 2016. "A Comparative Study of Spreadsheet Applications on Mobile Devices," Mobile Information Systems (2016).

25. Eraslan, E., İç, Y. T., and Yurdakul, M. 2016. "A New Usability Evaluation Approach for Touch Screen Mobile Devices," International Journal of Business and Systems Research (10:2-4), pp. 186-219. 